\title{
The Correlation between Nutritional Status, Genetic History and Non Genetic History with Mental Retardation Children at Sekolah Luar Biasa (SLB) Mandara in Kendari Municipality
}

\author{
Jafriati $^{1}$, Yusuf Sabilu ${ }^{2}$, Irma Yunawati ${ }^{3}$, Laode Ahmad Jazuli ${ }^{4}$ \\ \{jafriati@lecturer.uho.ac.id ${ }^{1}$, yusufsabilu@yahoo.com ${ }^{2}$, irmayunawati@gmail.com ${ }^{3}$, \\ ahmadjazuli_laode@lecturer.uho.co.id ${ }^{4}$ \} \\ Universitas Halu Oleo, Kampus Hijau Bumi Tridharma Anduonohu Jl. H.E.A. Mokodompit, Kendari, \\ Southeast Sulawesi 93232 Indonesia ${ }^{1,2,3,4}$
}

\begin{abstract}
Mental retardation is a mental disorder in lifelong, which is influenced by genetic and non-genetic factors, both before, during, and after birth. This study aimed to determine the correlation between nutritional status, genetic history, and non-genetic history with mental retardation children at SLB Mandara in Kendari Municipality. This study was an observational analytic study using a cross-sectional design. The population in this study was all of the children who have mental retardation at SLB Mandara Kendari as many as 54 students and the samples as many as 35 students. The sampling was done by using Stratified random sampling technique. Data analysis using a chisquare test with a confidence interval (CI) of $95 \%$ at a significance level of $p<0.05$. The results showed that there was a significant correlation between nutritional status (pvalue $=0.031$ ), genetic history (pvalue $=0.048$ ), maternal health history (pvalue $=0.003$ ), and pregnancy history (pvalue $=0.016$ ) with mental retardation children, and there was no correlation between the child's history (pvalue $=0.089$ ) and parenting history (pvalue $=0.249$ ) with mental retardation children at SLB Mandara in Kendari Municipality.
\end{abstract}

Keywords: nutritional status; genetic; not genetic; mental retardation.

\section{Introduction}

Mental retardation is a lifelong mental disorder, according to WHO (1998) in Sularyo and Kadim (2000) estimated that more than 120 million people worldwide suffer from this disorder [1]. According to the World Bank and the World Health Organization (WHO), as many as $15 \%$ of the world's population or 785 million people experience mental and physical disorders. Of the various types of physical and mental limitations that exist, mental retardation is one of them [2]. The prevalence of mental retardation in children under 18 years in developed countries is estimated to reach $0.5-2.5 \%$ and in developing countries, around $4.6 \%$. The incidence of mental retardation in developed countries ranges from 3-4 new cases per 1000 children in the last 20 years. The incidence of children with mental retardation ranges from 19 per 1000 live births [1].

Environmental Mental retardation is a world problem with big implications, especially in developing countries. According to the United Nations, until 2000, it was estimated that 
around 500 million people in the world had disabilities, and $80 \%$ were found in developing countries [2]. The results of an analysis from the Global Burden of Disease in 2004 found that $15.3 \%$ of the world's population experienced moderate disability, and $2.9 \%$ experienced severe disability. In the population aged $0-14$ years, the prevalence is $5.1 \%$ and $0.7 \%$, while in the population aged 15 years or more, $19.4 \%$ and $3.8 \%$ [3]. The population of people with disabilities in Indonesia according to the National Socio-Economic Survey (Susenas) in 2012 was $2.45 \%(6,515,500$ people) of the estimated $244,919,000$ Indonesian populations and mental retardation included in it. There was an increase in the prevalence of disability including mental retardation from 2003 to 2006 , from $0.69 \%$ to $1.38 \%$, then from 2009 to 2012 , from $0.92 \%$ to $2.45 \%$ of the total population in Indonesia [3]. According to Basic Health Research (2007), Southeast Sulawesi Province is included in 14 provinces that have disability prevalence (mental retardation included) above national prevalence $(19.5 \%$ ) which is $19.7 \%$ [4].

Data on students with disabilities who are enrolled in Special Schools (SLB) according to the Ministry of National Education (2009) are as many as 70,501 people and are included in the mental retardation category of 4,253 people [5]. In Southeast Sulawesi, the number of mentally retarded persons recorded in 2014 was 1,998 and distributed to each district, i.e. BauBau City, 240 people, Kendari City 230 people, Kolaka Regency 223 people, Buton Regency 220 people, As many as 200 people in Muna Regency, 195 people in North Konawe Regency, 185 people in Wakatobi Regency, 175 people in South Konawe Regency, 170 people in Bombana Regency and 160 people in Konawe Regency. This number can continue to increase from year to year, depending on the number of children with mental retardation enrolled in Special Schools [6].

According to Grossman (1973) in Sularyo \& Kadim (2000), mental retardation is a significant reduction in intellectual function and directly causes disruption of social adaptation and manifests during developmental times [1]. The high cases of mental retardation will cause more and more cognitive abilities of the affected community. If the case of disability continues to increase, human resources will decrease, and the quality of the population in Indonesia will also decrease [7]. Therefore mental retardation is a problem in the field of public health, social welfare, and education, both in children who experience mental retardation and family and society.

Based on the ICD-10 Classification of Mental and Behavioral Disorders (WHO, 1994) in Sularyo \& Kadim (2000), mental retardation is divided into 4 groups i.e. mild mental retardation (IQ 50-69), moderate mental retardation (IQ 35-49), severe mental retardation (IQ 20-34) and very severe mental retardation (IQ <20) [1]. According to Sularyo (1992) and Prasidio (1976) in Sularyo \& Kadim (2000) and Lumbantobing (2006), the occurrence of mental retardation cannot be separated from child development and which are influenced by genetic factors that determine the child's innate nature, and environmental factors (fostering includes food and nutrition, basic health care, sanitation, care including love, and teaching includes education and training) [1], [8]. Genetic factors have contributed $30-40 \%$ in determining brain development and children's intelligence level. Furthermore, the other factors that play a significant role are environmental factors, including meeting the needs of various nutrients needed to support the child's brain development process [7]. The causes of mental retardation are divided into three phases, i.e., prenatal, perinatal, and postnatal [1] causes including the child's history, maternal health history, pregnancy history, and parenting history. Short et al., (2013) stated that mental retardation is influenced by genetic and nongenetic factors, both before, during, and after birth [9]. 
Sekolah Luar Biasa (SLB), Mandara in Kendari Municipality, is one of the schools for children with mental retardation in Southeast Sulawesi Province which includes 3 levels of education i.e. elementary, middle and high school. Based on the observation of the number of students in the 2013/2014 data as many as 137 children, increased to 156 children in 2014/2015 and 2015/2016 as many as 151 children [10]. Based on these data, it is seen that there are still many children who experience mental retardation and need attention and handling. This study aimed to determine the correlation between nutritional status, genetic history, and non-genetic history with mental retardation children at SLB Mandara in Kendari Municipality.

\section{Method}

This study was an observational analytic study using a cross-sectional design. This study was conducted in November 2016 at SLB Mandara in Kendari Municipality. The population in this study was all of the school children at the elementary, middle, and high school levels at SLB Mandara in Kendari Municipality who experienced mental retardation as many as 54. The sample size was determined by using the Slovin formula to obtain a sample of 35 students. Sampling was carried out using Stratified random sampling technique. The sample representation at the education level was 19 elementary students, 13 middle school students, and 3 high school students. The variables in this study consisted of the independent variable, i.e. nutritional status, genetic history, non-genetic history (the child's history, maternal health history, pregnancy history, and parenting history) and the dependent variable, i.e., mental retardation children.

Nutritional status data obtained from measurements of body weight using body weight scale and height measurement using microtome on subjects (samples) based on the nutritional status assessment of BMI-for-age with WHO 2005 reference cut-off z-score processed using WHO Anthropos. Genetic history and non-genetic history (the child's history, maternal health history, pregnancy history, and parenting history) were collected using a structured questionnaire that was asked by the researcher to the respondent (mother of the research subject). For data of mental retardation, children were obtained from secondary data derived from the diagnosis of SLB Mandara in Kendari Municipality. Data were analyzed using computer software specifically for statistical analysis using univariate frequency distribution and bivariate analysis with chi-square test with a 95\% confidence interval (CI) at a significance level of $\mathrm{p}$-value $<0.05$.

\section{Results}

The research subjects are the children of SLB Mandara in Kendari Municipality who were elementary, junior, and senior high school students with the highest samples are coming from elementary education level. Based on the age of the children, most children mental retardation are 11-15 years old as many as 17 students (48.6\%). The age of the child in this study does not reflect the level of education that is appropriate to the age of normal children in general. This is because the ability / intellectual function in children with mental retardation is below average, accompanied by the inability of the adaptation function [11]. Most of the research subjects were male, as many as 21 students $(60.0 \%)$. This is consistent with the many studies 
stated by WHO (1998), Prasidio (1976) \& Ramelan (1992) in Sularyo \& Kadim (2000) and (Prasa, 2012) that the incidence of mental retardation is more in boys than in women $[1,2]$.

Age of mothers from mental retardation children was distributed almost evenly, except for mothers aged 21-30 years, which was only 1 person $(2.9 \%)$. This means that most mothers are already in the stage of maturity (adult) in the face of children who experience mental retardation, so it is likely that children with mental retardation get good treatment. Parents of children with mental retardation must accept shortcomings and help their children to adjust to these deficiencies. Parents must realize that there are many things that can be done to help children meet their needs. If the child knows that parents pay attention to him, then this child is helped a lot in adjusting to the outside world [12].

Most parents of children who experience mental retardation have a fairly good education, i.e., at the level of tertiary education (PT) as many as 17 people (48.6\%) and most parents do not work (as housewives / IRT) as many as 25 people (71.4\%). This can support parents in dealing with children with mental retardation because with high education; parents can know and understand the best things to give to their children and parents (mothers) who do not work can devote full attention to mental retardation children. Jannah and Anita (2012) suggested parental stimulation can help in improving child development. Parents have a great influence on the development of children who experience mental retardation. Stimulation can be done by playing exercises. Children who get targeted stimuli will develop faster than children who lack stimulation [13]. (Table 1).

The result showed that the frequency distribution of research subjects who had moderate mental retardation $(77.1 \%)$ was higher than the subjects who experienced mild mental retardation. The results of the study also obtained that most of the research subjects were underweight (60.0\%). Based on genetic history, most have no history (57.1\%). Judging from the child's history, there was no significant difference, i.e., a little more had the child's history (51.4\%) based on maternal health. 
Table 1. Basic characteristics of mental retardation children and parents

\begin{tabular}{lcc}
\hline Basic characteristics of mental retardation children and parents & $\mathrm{n}$ & $\%$ \\
\hline Children's age & 7 & 20.0 \\
$6-10$ years & 17 & 48.6 \\
$11-15$ years & 11 & 31.4 \\
$16-20$ years & & \\
\hline Children's sex & 21 & 60.0 \\
Male & 14 & 40.0 \\
Female & & \\
\hline Respondents' age (mother) & 1 & 2.9 \\
$21-30$ years & 11 & 31.4 \\
$31-40$ years & 12 & 34.3 \\
$41-50$ years & 11 & 31.4 \\
$>50$ years & & \\
Parents' education level & 7 & 20.0 \\
Elementary school & 41.4 \\
Junior high school & 4 & 20.0 \\
Senior high school & 7 & 48.6 \\
University/tertiary education & 17 & \\
\hline Parents' occupation & & 71.4 \\
Not working (Housewife) & 25 & 8.6 \\
Entrepreneur & 3 & 20.0 \\
Civil servant & 7 & \\
\hline
\end{tabular}

Table 2. Frequency distribution of the variables studied

\begin{tabular}{ccc}
\hline Studied variables & $\mathrm{n}$ & $\%$ \\
\hline Mental retardation & 27 & 77.1 \\
& 8 & 22.9 \\
Moderate Mild & & \\
Nutritional status & 14 & 40.0 \\
Normal & 21 & 60.0 \\
& & \\
Underweight & & \\
Genetic history & 15 & 42.9 \\
Available & 20 & 57.1 \\
Unavailable & & \\
Children history & & \\
& & \\
\hline
\end{tabular}


Available

\begin{tabular}{ccc} 
Unavailable & & \\
\hline Maternal health history & 24 & 68.6 \\
Available & 11 & 31.4 \\
Unavailable & & \\
Pregnancy history & & 28.6 \\
Available & 10 & 71.4 \\
Unavailable & 25 & \\
Parenting history & & \\
Available & 15 & 42.9 \\
Unavailable & 20 & 57.1 \\
\hline
\end{tabular}

History, most of them had a history (68.6\%). Judging from pregnancy history and parenting history, most of them had no pregnancy history $(71.4 \%)$ and no parenting history $(57.1 \%)$ (Table 2).

Table 3. The correlation between nutritional status, genetic history and non-genetic history with mental retardation children

\begin{tabular}{|c|c|c|c|c|c|}
\hline \multirow{3}{*}{ Research variables } & \multicolumn{4}{|c|}{ Mental retardation } & \multirow{3}{*}{$\mathrm{P}_{\text {value }}$} \\
\hline & \multicolumn{2}{|c|}{ Moderate } & \multicolumn{2}{|c|}{ Mild } & \\
\hline & $\mathrm{n}$ & $\%$ & $\mathrm{n}$ & $\%$ & \\
\hline \multicolumn{6}{|l|}{ Nutritional status } \\
\hline Normal & 6 & 54.5 & 5 & 45.5 & 0.031 \\
\hline Underweight & 21 & 87.5 & 3 & 12.5 & \\
\hline \multicolumn{6}{|l|}{ Genetic history } \\
\hline Available & 14 & 93.3 & 1 & 6.7 & 0.048 \\
\hline Unavailable & 13 & 65.0 & 7 & 35.0 & \\
\hline \multicolumn{6}{|l|}{ Children history } \\
\hline Available & 16 & 88.9 & 2 & 11.1 & 0.089 \\
\hline Unavailable & 11 & 64.7 & 6 & 35.3 & \\
\hline \multicolumn{6}{|l|}{ Maternal health history } \\
\hline Available & 22 & 91.7 & 2 & 8.3 & 0.003 \\
\hline Unavailable & 5 & 45.5 & 6 & 54.5 & \\
\hline \multicolumn{6}{|l|}{ Pregnancy history } \\
\hline Available & 5 & 50.0 & 5 & 50.0 & 0.016 \\
\hline Unavailable & 22 & 88.0 & 3 & 12.0 & \\
\hline Parenting history & & & & & \\
\hline
\end{tabular}




\begin{tabular}{cccccc}
\hline Available & 13 & 86.7 & 2 & 13.3 & 0.249 \\
Unavailable & 14 & 70.0 & 6 & 30.0 & \\
\hline
\end{tabular}

Statistical test results also showed that there was a significant correlation between nutritional status $\left(\mathrm{p}_{\text {value }}=0.031\right)$, genetic history $\left(\mathrm{p}_{\text {value }}=0.048\right)$, maternal health history $\left(\mathrm{p}_{\text {value }}\right.$ $=0.003)$ and pregnancy history $\left(\mathrm{p}_{\text {value }}=0.016\right)$ with mental retardation children $\left(\mathrm{p}_{\text {value }}<0.05\right)$, while the child's history $\left(\mathrm{p}_{\text {value }}=0.089\right)$ and parenting history $\left(\mathrm{p}_{\text {value }}=0.249\right)>0.05$ means that there was no correlation with mental retardation children at SLB Mandara in Kendari Municipality (Table 3).

\section{Discussion}

\subsection{The correlation between nutritional status and mental retardation children at SLB Mandara in Kendari Municipality}

The majority of children with mental retardation are in the category of having poor nutritional status $(87.5 \%)$, this can be caused by dental and oral health that is not maintained so that difficulty in swallowing food can ultimately affect the nutritional status of children. This is consistent with the opinion of Salmiah (2010), which states that generally, patients with mental retardation have lower oral cavity health and oral hygiene compared to people without developmental disabilities [14]. Infectious diseases such as diarrhea can aggravate the nutritional status of children, especially if food intake does not meet the needs of children in a day. In the end, the child's weight will decrease, and if it continues continuously the child will become thin and there will be a problem of malnutrition [15].

From the observations of the researchers, that children with nutritional status are less likely to prefer to choose food, these children use their time more to play so that at mealtime, they prefer to continue playing rather than to eat, poor family economic conditions (poverty), and incorrect eating habits also influence the condition of malnutrition. Food imbalances (both deficits and surpluses) will interfere with bodily functions that have negative effects on nutritional and health conditions. Other factors that can affect malnutrition are the purchasing power and food security in the family [15], which is influenced by family income, which in this study most mothers with children with mental retardation do not have a job (IRT) so they do not can support family income which ultimately affects the family's ability to obtain food.

This study showed that there was a correlation between nutritional status and mental retardation children (value $=0.031$ ). This is in line with research conducted by Ingtyas (2004) in his research on food consumption, nutritional status, and children's health mental retardation in Medan City, where in his study as many as 26 samples, including 61.5\% experienced by 16 children with retardation mentally experiencing underweight, and the remaining $38.5 \%$ was experienced by 10 children with mild mental retardation [16]. Due to lack of nutrition in the body's processes, the body becomes lethargic (weak) and lacks the enthusiasm to perform various activities; such a condition of the body will certainly cause a lot of harm, become lazy, susceptible to infections such as coughs, colds, and diarrhea. Malnutrition at a young age can affect mental development and thinking ability [17]. This is what causes children to be lazy to learn and exacerbate the condition of children who experience mental retardation, which causes the child's thinking power to decrease.

Malnutrition at the time of growth can result in a reduction in the number of brain cells from a normal amount. This, of course, will affect the work of the brain. Research conducted 
by Wibowo (2013) has proven that nutritional status in children has a positive impact on their intelligence [18]. Meeting the needs of various nutrients is needed to support the child's brain development process [7].

The correlation between genetic history and mental retardation children at SLB Mandara in Kendari Municipality Most children with moderate mental retardation have a genetic history in their family (93.3\%). Based on the respondent's statement, the existence of a family history experienced by a child with mental retardation at SLB Mandara was due to another family who suffered from mental retardation. Based on the results of the study, relatives of children with mental disorders were siblings, grandfathers, grandmothers, siblings, and mothers. Prasedio (1976) in Sularyo \& Kadim (2000) states that if a family suffers from mental retardation other than a child, such as his uncle or grandfather, then it can be concluded that the cause of mental retardation is due to offspring [1].

The existence of a history of mental retardation or other hereditary diseases in the family of the mother or father causes an increase in the likelihood of the disorder being revealed to the child. The risk of retardation in a child with normal parents and siblings is less than $2 \%$, whereas if both parents and siblings suffer retardation, the risk is $40 \%-70 \%$ [19]. This study showed that there was a correlation between genetic history and mental retardation children (value $=0.048$ ). Genetic factors have contributed $30-40 \%$ in determining brain development and children's intelligence level [7]. The occurrence of mental retardation cannot be separated from the child's growth and development, which is influenced by genetic factors that determine the child's innate nature [1], [8].

The results of Boeree (2007) study that if in a family there is no other family suffering from mental retardation, the chances of giving birth to a child with mental retardation are lacking, but if there is a birth of mental retardation it may be influenced by other factors such as the presence of prenatal disease, maternal health when containing, and other factors that cause mental retardation [1], [20]. The occurrence of mental retardation can be caused by several factors including genetic factors or also abnormalities in chromosomes [9], [21], [22].

\subsection{The correlation between child history and mental retardation children at SLB Mandara in Kendari Municipality}

The result showed that children who had a medical history or who had no medical history during the womb, at and after birth were not much different in facing (experiencing) mental retardation ( $\mathrm{p}$-value $=0.089$ ). Therefore, it had nothing to do with the incidence of mental retardation. Based on interviews conducted on respondents, children who did not have a medical history when the child was still in the womb, at and after birth, they were in good condition and did not show significant symptoms that caused the children to experience mental retardation. However, this needs to be followed up because it is not yet known whether during pregnancy, the mothers always consulted to get antenatal care to health workers/services or not. Antenatal care is an effort to maintain maternal and infant health during pregnancy as well as efforts to reduce maternal and perinatal morbidity and mortality [23].

For children who had a medical history when the child was still in the womb, during and after birth, there were several things that are likely to cause a child to experience mental retardation including low birth weight (LBW), childbirth performed Caesarean because of the position/location of the baby during the womb abnormal, no breastfeeding is given to the child, and the child has fallen, causing the child's head to hit. Mental retardation can be caused by infants with low birth weight (LBW), neonatal asphyxia, and seizures. The prevalence of 
LBW is estimated to be $15 \%$ of all births in the world, with a limit of 3.3 to $38 \%$ and is more common in developing or low socio-economic countries. The most common causes of LBW are premature birth, maternal age during pregnancy, parity, fetal factors such as hydramnios, Gemelli, and chromosomal abnormalities [24]. Anantaputro (2015) states that a baby with the weight less than 2,500 grams needs to be treated because the baby's immune system is easily disturbed by disease. The lighter the baby's weightthan the greater the likelihood of suffering from mental disorders, motoric disorders, and speech disorders [25]. Mothers who come from families with low socioeconomic status tend to be inadequate for nutritional needs that are good for the fetus as a result of low birth weight babies (LBW) and short body lengths and tend to experience malnutrition, so that child development is disrupted [24].

The risk of premature birth will be higher with the position of the breech baby. Lumbantobing (2006) states that risk factors for mental retardation are if the condition is born with cunam or breech birth [8]. Prenatal factors such as infection (virus, parasite), chemicals, nutrition, physical, immunological (blood group incompatibility), endocrinologist, placental abnormalities, intrauterine hypoxia, perinatal factors such as prolonged labor, asphyxia, birth trauma, prematurity, site abnormalities and factors post / postnatal care, such as infection, nutrition, stimulation, trauma, chemicals, illness in infancy, protection of parents and culture will risk children experiencing mental retardation [22], [24, [26]. Breast milk contains all the nutrients needed for infant growth and development; breast milk also contains immunity or antibodies that protect children from infection. Besides that, there are still many other advantages of breast milk that spur physical growth and mental development of children's intelligence [15]. Other factors that affect mental retardation are trauma to the head because the baby falls, an infection of the brain, for example, by cerebral meningitis, tropical malaria, nutrition deficiency [27].

\subsection{The correlation between maternal health history and mental retardation children at SLB Mandara in Kendari Municipality}

Most children with mental retardation in the medium category had a medical history faced by the mother $(91.7 \%)$. Based on the respondent's statement, a history of illness or health problems experienced by the mother includes anemia, hypertension, mumps, and the mother often experiences pain when pregnant. Iodine deficiency can affect a child's mental development, sometimes also resulting in mental retardation. Based on the research also that iron deficiency anemia, although mild, can result in the delay of psychosocial development of children [8].

This study showed that there was a correlation between maternal health history and mental retardation children $(\mathrm{p}$-value $=0.003$ ). Prenatal time contributes to maternal and fetal mortality and morbidity, including neurological disorders, growth and mental development of children. Ten prenatal factors (advanced maternal age, maternal black race, low maternal education, third or higher parity, mothers who consume alcohol, pregnant women who smoke, DM in pregnant women, maternal hypertension, maternal epilepsy, and maternal asthma) significantly increase the incidence mental retardation [28]. If when the mother is pregnant, she suffers from diseases such as anemia, goiter at the time of containing young, hypertension and taking sedative drugs, then a bad impact will occur on the fetus, where babies born will suffer from toxemia which is an event of blood poisoning resulting in abnormality in nervous system [27]. 
Pregnancy in older women, especially after 35 years has a risk of giving birth to children with mental retardation because the mother also has an accompanying disease [29], [30]. Pregnancy in old age, especially after 40 years, has a worse risk; this is because at that age, often accompanied by hypertension, diabetes, and uterine myoma. The incidence of congenital anomalies is also high, generally down syndrome [24].

\subsection{The correlation between pregnancy history and mental retardation children at SLB Mandara in Kendari Municipality}

Most children with moderate mental retardation do not have a history of pregnancy $(88.0 \%)$ such as consuming alcohol, smoking, drugs, stress, abortions, and unexpected pregnancy. However, other factors that also affect maternal and fetal health are antenatal care. Based on interviews, it was found that some mothers had never had a prenatal checkup because they considered that the womb was in good condition and had no problems, even though antenatal care was very important during pregnancy. This is consistent with the statement of Erlina et al., (2013) that antenatal care is one of the important stages that must be performed by pregnant women through an obstetrician or midwife with a minimum of four examinations during pregnancy, i.e., in the first, second and third trimester of pregnancy. It's a good idea to have a pregnancy check-up once a month from the age of the womb to nine months [31].

This study showed that there was a correlation between pregnancy history and mental retardation children $(p$-value $=0.016)$. Based on this study, it was also observed that some mothers who have children with mild mental retardation and are stating that during pregnancy the mother had consumed alcoholic beverages, taking anti-pregnancy drugs, taking drugs that are sold freely and without a prescription, taking herbs, experiencing stress, an unexpected pregnancy, had an abortion attempt, had abortion in a previous pregnancy, had fallen, the age of childbirth in the first pregnancy $<16$ years or $>35$ years, gestational age $<9$ months and the mother rarely examined her pregnancy.

This behavior can cause children to experience mental retardation. This is consistent with the statement of Sularyo and Kadim (2000) that mental retardation is caused by alcohol intoxication in the fetus because pregnant women consume alcoholic beverages [1]. Consumption of drugs, alcohol, or smoking is one of the factors that cause a bad development effect for the baby [28]. Babies born prematurely before 27 weeks of gestation will increase the incidence of mental retardation because premature children have less than normal weight [32]. Other researchers explain that mental retardation can be caused by babies with low birth weight (LBW), asphyxia, neonatorum, and seizures [24]. Poor maternal conditions such as the age of the mother who is too old, supported by low socioeconomic and physical, mental and social environment that is not good can have a negative impact on pregnancy until the birth of a child [32], aged mother $>35$ years and over during pregnancy have a higher risk of giving birth to children with mental retardation [24] and children born to mothers whose pregnancies get antenatal care properly will reduce the incidence of mental retardation [32].

\subsection{The correlation between parenting history and mental retardation children at SLB Mandara in Kendari Municipality}

Children with moderate mental retardation have a history of care (86.7\%) slightly greater than children with moderate mental retardation who have no parenting history. Based on the 
statement of respondents that parenting history of children was fully carried out by the mother herself and usually received care from the eldest brother, neighbors, and other relatives. Parenting is a description of the attitude and behavior of parents and children in interacting, communicating during caring activities [33]. Parenting patterns such as parental attitudes, family habits, and family views will influence the formation of children's independence. Families who familiarize their children to be independent of an early age will foster independence to their children [34] as well as children with mental retardation.

This study showed that there was no correlation between parenting history and mental retardation children ( $p$-value $=0.249$ ). This was probably caused by mothers who play a big role in the care of children cannot fully do this role because the mother must take care of the household and may also earn additional income for the family so that the care cannot be optimal. This is consistent with the statement of Tuegeh et al., (2012) that gender influences in terms of parenting roles, usually mothers are more instrumental in educating and caring for children [34]. Also, mothers have other roles as housekeepers, caregivers, and educators of children, family protectors, and additional family breadwinners as well as certain social groups in the society [35].

Respondents in this study stated that childcare is not only done by mothers but also by other people such as older children, babysitters, other relatives, and neighbors. This can allow as long as the child in care other than the mother, has fallen, causing the child's head to hit, causing a concussion and the like. This is consistent with Anantaputro's statement (2015) that many accidents result in severe concussions and are usually the cause of mental retardation [25]. Also, according to Satoto (1990) in Indrawati (2016), children who grow normally will have motor skills that are appropriate for their age. If there is a disruption to the children's motor development, it will affect their growth and development in the next period [36].

Parents have a very important role in educating and training their children in the process of development. The responsibility and role of parents are needed, especially for children who experience mental retardation to help them develop their adaptive social behaviors, i.e., the ability to be independent. Thus, parents must understand the most effective ways to educate and shape their children's independence [8]. Based on interviews, it is known that mothers pay more attention to children who are mentally challenged than their normal children because they think that normal children are still able to do everything themselves but not so with children who experience mental retardation. Even so, mother and family should teach independence as much as possible to children who experience mental retardation. This is consistent with the statement of Tuegeh et al. (2012) that the role of a good family can form independence in children, as well as in children with mental retardation. Meanwhile, the role of a bad family will slow down the independence of children. Therefore, the conclusion is that children's independence depends on the family [34].

\section{Conclusion}

There was a correlation between nutritional status, genetic history, maternal health history, and pregnancy history (non-genetic) with mental retardation children. However, other nongenetic histories of the child history and parenting history have no correlation with mental retardation children at SLB Mandara in Kendari Municipality. Therefore, further study is needed to examine the problems of mental retardation in children more deeply, particularly qualitative study. 


\section{References}

[1] Sularyo TS, Kadim M.: Mental retardation [Retardasi mental], Sari Pediatri. Vol. 2, pp. 170-177 (2000)

[2] Prasa B A.: Stress \& coping of parents with mental retardation children Stres \& koping orang tua dengan anak retardasi mental, EMPATHY Jurnal Fakultas Psikologi. Vol. 1, pp.2-10 (2012)

[3] Kementerian Kesehatan Republik Indonesia (Kemenkes RI).: Situasi Penyandang Disabilitas Jakarta, Kemenkes RI.pp.1-64 (2014)

[4] Departemen Kesehatan Republik Indonesia (Depkes RI).: Riset Kesehatan Dasar (RISKESDAS) 2007, Jakarta;Depkes RI.pp.1-384 (2008)

[5] Kementerian Kesehatan Republik Indonesia (Kemenkes RI).: Pedoman Pelayanan Kesehatan Anak Di Sekolah Luar Biasa (SLB) Bagi Petugas Kesehatan, Jakarta, Indonesia: Kemenkes RI.pp.23-40 (2011)

[6] Badan Pusat Statistik Sulawesi Tenggara (BPS Sultra).: Penyandang Cacat Menurut Jenisnya Dan Kab/Kota (Kendari, Indonesia: BPS Sultra) (2014)

[7] Pratiwi I C, Handayani O W K, Raharjo BB.: Cognitive ability of mental retardation children based on nutritional status [Kemampuan kognitif anak retardasi mental berdasarkan status gizi]. Public Health Perspective Journal. Vol. 2, pp. 19-25. (2017)

[8] Lumbantobing S M.: Anak dengan Mental Terbelakang], (Jakarta, Indonesia: Universitas Indonesia).pp.19-32 (2006)

[9] Short J R, Gray O P, \& Dodge J A.: Pediatric Synopsis [Sinopsis Pediatri] (Tangerang, Indonesia: Binarupa Aksara Publisher).pp.13-19 (2013)

[10] Sekolah Luar Biasa (SLB) Mandara Kendari.: Secondary Data; Number of Students [Data Sekunder; Jumlah Siswa] (Kendari, Indonesia: SLB Mandara. (2016)

[11] Wenar C, \& Kerig P.: Developmental psychopathology from infancy through adolescence (Singapore: The Mc Graw Hills Companies, Inc).pp.44-59 (2006)

[12] Semiun Y.: Kesehatan Mental 2 Gangguan-Gangguan Kepribadian, Reaksi-Reaksi Simtom Khusus, Gangguan Penyesuaian Diri, Anak-Anak Luar Biasa, dan Gangguan Mental yang Berat (Yogyakarta, Indonesia: Kanisius). pp. 23-52. (2006)

[13] Jannah M \& Anita N.: Parent Experience that Has Mental Retardation Children in Pekalongan City. (Pekalongan, Indonesia: STIKES Muhammadiyah Pekajangan). pp. 10-18. (2012)

[14] Salmiah S.: Retardasi Mental (Medan, Indonesia: Dentistry Faculty, North Sumatera University. Fakultas Kedokteran Gigi Universitas Sumatera Utara. pp.1-30 (2010)

[15] Soekirman.: Healthy Life of Balanced Nutrition in the Human Life Cycle. Hidup Sehat Gizi Seimbang dalam Siklus Kehidupan Manusia. Jakarta, Indonesia: Gramedia Pustaka Utama. (2014)

[16] Ingtyas T F.: Food Consumption, Nutritional Status and Health of Mental Retardation Children in Medan Municipality. Konsumsi Pangan, Status Gizi Dan Kesehatan Anak Retardasi Mental Di Kota Medan. Bogor, Indonesia: Institut Pertanian Bogor. (2004)

[17] Almatsier S.: Basic Principles of Nutrition Science (Prinsip Dasar Ilmu Gizi). Jakarta, Indonesia: Gramedia Pustaka Utama. (2006)

[18] Wibowo.: Hubungan Status Gizi dan Intelligence Quotient Terhadap Prestasi Belajar Siswa Siswi SD Bintaro Tahun Ajaran 2010-2011. Universitas Pembangunan Veteran. pp. 1-15. (2013)

[19] Tomb D A.: Buku Saku Psikiatri. Jakarta, Indonesia: EGC. Pp.1-14 (2003)

[20] Boeree C G.: Personality Theories. Yogyakarta, Indonesia: Ar Ruzz Media. Pp.11-19 (2007)

[21] Aziz H A.: Pengantar Ilmu Keperawatan Anak. Jakarta, Indonesia: Salemba Medika. Pp.2345(2009)

[22] Ismiarni.: Factors Correlated to Acceptance of Parents towards Mental Retardation Children at SDLB Minasatene Pangkep. (Makassar, Indonesia: Yayasan Gema Insan Akademik).pp.10-20 (2007) 
[23] Manuaba.: Obstetrics, Gynecology \& Family Planning. Ilmu Kebidanan, Penyakit Kandungan \& Keluarga Berencana. (Jakarta, Indonesia: EGC). Pp. 102-120 (1998)

[24] Irianto.: Biology of Reproduction. (Bandung, Indonesia: Alfabeta). pp.29-48 (2014)

[25] Anantaputro.: History of Mental Retardation (Jakarta, Indonesia: EGC).pp.40-55 (2015)

[26] Effendi.: Psycho Pedagogic Education for Children with Disabilities. Jakarta, Indonesia: Bumi aksara). Pp.13-27 (2006)

[27] Kartono.: Child Psychology. (Bandung, Indonesia: CV Mandar Maju). Pp.50 (2007)

[28] Huang J, Zhu T, Qu Y, \& Mu D.: Prenatal, perinatal \& neonatal risk factors for intellectual disability: a systemic review \& meta-analysis, Plos One. Vol. 11, pp. 401-423 (2016)

[29] United Nations Children's Fund (UNICEF).: Children with Disabilities. (2013)

[30] Nisbett R, Blair C, Dickens W, Flynn J, Halper D, \& Turkheimer E.: Intelligence: new findings and theoretical developments. American Psychologist. Vol. 67, pp. 130-159. (2012)

[31] Erlina R, Larasati T A, \& Kurniawan B.: Factors affecting pregnant women towards antenatal care visit at Inpatient Room of Community Health Centre of Panjang in Bandar Lampung Medical Journal of Lampung University. Vol. 2, pp. 29-34. (2013)

[32] Nurochim E, Indarto D, \& Prayitno A.: Association between maternal age at pregnancy, socioeconomic status, physical environment, prenatal, perinatal, postnatal history and the risk of mental retardation, Journal of Maternal and Child Health. Vol. 1, pp. 119-130. (2016)

[33] Hasan M.: Education for Early Childhood. (Yogyakarta, Indonesia: Diva Press).pp. 80-97 (2010)

[34] Tuegeh J, Rompas F, \& Ransun D.: The role of family in establishing mental retardation children at Foundation of disabled child development of Manado in 2011. JUIPERDO. Vol. 1, (1), pp. 3035. (2012)

[35] Setiadi.: Concept and Process of Family Nursing. (Yogyakarta, Indonesia: Graha Ilmu).pp.48-62 (2008)

[36] Indrawati D R.: Relationship between Nutritional Status and Head Circumference with Rough Motoric Ability of 1-2 Years Old Children in Brati Subdistrict, Grobogan Regency. (Semarang, Jawa Tengah: Universitas Diponegoro). Pp. 32-40 (2016) 